Winter 2005

\title{
The Globalization of Multicultural Education
}

Margaret Sutton

Indiana University

Follow this and additional works at: https://www.repository.law.indiana.edu/ijgls

Part of the Education Law Commons, and the International Law Commons

\section{Recommended Citation}

Sutton, Margaret (2005) "The Globalization of Multicultural Education," Indiana Journal of Global Legal Studies: Vol. 12 : Iss. 1 , Article 3.

Available at: https://www.repository.law.indiana.edu/ijgls/vol12/iss1/3

This Symposium is brought to you for free and open access by the Law School Journals at Digital Repository @ Maurer Law. It has been accepted for inclusion in Indiana Journal of Global Legal Studies by an authorized editor of Digital Repository @ Maurer Law. For more information, please contact rvaughan@indiana.edu.

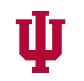

JEROME HALL LAW LIBRARY

INDIANA UNIVERSITY

Maurer School of Law
Blooming ton 


\title{
The Globalization of Multicultural Education
}

\author{
Margaret Sutton*
}

\section{INTRODUCTION}

The appearance of edited volumes on a topic signals the maturation of scholarly reflection upon it within the field of comparative education. Such is the case with "multicultural education." In common usage in the United States, multicultural education generally refers to education about different ethnic groups that comprise the U.S. population. Indeed, the vast majority of the literature produced on the subject consists of curricular units for teaching about African-Americans, Native Americans, Latinos/Chicanos, or various AsianAmerican groups. As dialogue on cultural difference and education has spread to other nations, it has become more sharply focused on complex issues of identity, diversity, and citizenship.

Advocates of multicultural education define it as having either two or three key features. James Banks, a leading voice in the field, defines three central concerns addressed by multicultural education: validating the identities of socially oppressed groups; teaching the history of exploitation and resistance to it; and providing empowering education to oppressed groups. ${ }^{2}$ Others reduce these features to two: "the 'recognition of diversity' strand [and] the 'social equality' strand."” Scholars of multicultural education agree that it is a social movement for educational reform that initially grew out of civil rights movements in the United States, particularly efforts for the complete enfranchisement of African-Americans. ${ }^{4}$

* Associate Professor of Educational Leadership and Policy Studies, Indiana UniversityBloomington; M.A. (Philosophy of Education), University of British Columbia, Canada (1978); Ph.D. (International Development Education), Stanford University (1991).

1. See James A. Banks, Diversity and Citizenship Education: Global Perspectives (2004) [hereinafter Diversity and Citizenship Education]; C.A. Grant \& J.L. Lei, Global Constructions of Multicultural Education: Theories and Realities (2001) [hereinafter Global Constructions of Multicultural Education]. See generally Carlos Alberto Torres, Democracy, Education, and Multiculturalism: Dilemmas of Citizenship in a Global World (1998) (discussing theories of citizenship and multiculturalism).

2. See generally Multicultural Education: Issues and Perspectives 3-25 (James A. Banks \& Cherry A. McGee eds., 5th ed. 2004).

3. W. Kymlicka, Foreword to Diversity and Citizenship Education, supra note 1, at xiii-xviii.

4. See generally John McFadden et al., Multicultural \& Globad/International Education: Guidelines for Programs in Teacher Education (1997). 
The concerns of "multicultural education"-equality of educational access on the one hand and institutionalized recognition of historical inequalities on the other--are a global phenomenon of the twenty-first century. The way that they play out in each nation, however, is both historically specific and transnationally formed. This paper discusses ways in which concerns about multicultural education have spread around the world in the past ten to twenty years and how the meaning of the term and the questions surrounding it have changed as diversity itself has become an educational issue in diverse national contexts. Loosened from its mooring in the United States' civil rights movement, multicultural education has become a rubric_or foil—for a certain arena of educational reform discourse around the world.

Whatever its specific connotations, and there are many, the term "multicultural education" speaks to questions of how school children are taught about their own social identity and the identity of others. As I argue in part one, the logic of mass schooling in nation-states already contains contradictions that sooner or later will raise questions about multiculturalism in any educational system. However, the "epochal" dimensions of globalization, such as wide-scale human migration and intensification of global communication, have complicated social identities within many nations and therefore stimulated public debate on how pluralism is recognized in the curriculum and pedagogy of national school systems. The cultural and economic trends, which have been concomitant with globalization, fuel national debates on multiculturalism in contradictory fashions. In part two I illustrate how, in the case of language in educational policy, globalization stimulates both greater acceptance of bilingual education and, in many communities, less acceptance of it. The paper concludes with an argument that the issues associated with multicultural education increasingly become an aspect of global educational debate; they converge around a common perspective of intercultural education.

\section{Citizenship, Difference, and Mass Education}

The institutionalization of mass, state-sponsored, formal education around the world carries in itself the seeds from which debate over multicultural education grows within different nations. As long noted by world systems theorists 
such as Arnoves and Ramirez, mass schooling carries with it a universal cultural blueprint. That blueprint includes the value of meritocracy and thus, by implication, the value of equity in education. Yet, as has long been clear in most nations, educational opportunity is differentially available to socially different groups. While the appearance of scholarly work that explicitly connects multiculturalism with educational systems around the world is relatively new, interest in educational equity is an enduring theme of comparative education. Since its inception over 100 years ago, questions about equal access to education within nations and relative equality of access across nations have been central concerns for the field of comparative education. ${ }^{?}$

Social pluralism is a reality in most, if not all, contemporary nations. In what nation, aside perhaps from the Democratic Republic of Korea, do all children speak the same mother tongue? In what country do all share a common religion, ethnicity, race, or caste? Differences in social identity can fundamentally determine access to education, experiences in the formal education system, and the meaning and value of educational credentials in the lives of those who hold them. Such differences have long histories in most nations. Yet the landscape of differences varies across nations. Most post-colonial nations have been formed on territories defined by colonial rulers, which often cut through regions encompassing linguistic, ethnic, or other culturally defined groups. Thus, most post-colonial nations of Africa and Asia are culturally diverse in their formation. But so too are the "older" nation-states such as Germany and the United Kingdom, as Anderson reminds us in Imagined Communities. ${ }^{8}$ The nations of the Americas include communities of indigenous people who were subjugated by their colonizers-as does South Africa. European post-colonizing nations, including France and the United Kingdom, have also been labor magnets for former colonial subjects, but so too have oil-rich Gulf states. Refugees of war and civil conflict have sought refuge not only in Europe and the Americas, but in far larger numbers across

5. See generally Robert F. Arnove, Comparative Education and World Systems Analysis, 24 Comp. Educ. Rev. 48 (1980) (calling for a world system, as opposed to a nation-state, analysis of education).

6. See generally John Boli \& Francisco O. Ramirez, Compulsory Schooling in the Western Context, in Emergent Issues in Education: Comparative Perspectives (Robert F. Arnove et al. eds., 1992) (discussing generalized explanations for the development of mass schooling in the West).

7. See Robert F. Arnove, Introduction to Comparative Education: The Dialectic of the Global and the Local 1, 1-2 (Robert F. Arnove \& Carlos Alberto Torres eds., 2d ed. 2003).

8. B.R.O.G. Anderson, Imagined Communities: Reflections on the Origin and Spread of Nationalism (Rev. \& extended ed. 1991). 
nation-state borders in Africa. In short, conquest, migration, and diaspora have resulted in pluralism of all sorts. The range of diversities makes it difficult to define typologies of pluralism across nation-states. Moreover, the lived experience of cultural identities may make such taxonomizing beside the point. This point is well made by Malkki's study of Burundian refugees in Tanzania. Working with migrants living in cities as well as in camps, she makes the important observation that adopting a specifically Burundian identity is far more salient and productive for those in refugee camps than those whose domiciles are Tanzanian cities, where assimilation is a more functional orientation. ${ }^{9}$ Ultimately, it is not possible a priori to specify which differences matter in which time and place, as Anthony Marx reminds us in his study on the history of racism, nationalism, and social movements in Brazil, the United States, and South Africa. ${ }^{10}$

Each national debate concerning cultural difference and education is thus embedded in the topography of diversity that is unique to that nation. Knowing the "lay of the land" provides critical context for understanding each debate. However, the universal features of mass schooling as induction into civil society provide a common framework for the creation of those issues that are now being viewed as "multiculturalism." As educational systems have grown to incorporate a majority of each nation's children, at least at the primary level, individuals from socially oppressed groups have gained the skills to advocate for educational equality and the credentials that make their advocacy efforts credible. Demands for equal educational opportunity, a central motivating force behind multicultural education, can thus be viewed as a quintessentially "modern" project. Commitment by the state to basic universal education entails some form of public attention to educational inequality because meritocracy is an intrinsic norm of the institution.

Controversies connected to multicultural education go to the heart of the meaning of citizenship in a nation-state. Mass, state-sponsored schooling has universally promoted some concept of citizenship in a nation. Among the many purposes and objectives ascribed to national school systems, the creation of national subjects shares historical primacy and endurance with the objective of fostering economic growth. The reports of Horace Mann on the new Massachusetts

9. See Litsa H. Malkki, Purity and Exile: Violence, Memory, and National Cosmology Among Hutu Refugees in Tanzania 197-205 (1995).

10. See generally Anthony W. Marx, Making Race and Nation: A Comparison of South Africa, the United States, and Brazil (1998). 
school system in the mid-1800s promote the transmission of "republican virtues" and knowledge of political institutions as central goals of common schooling for residents of the United States-as much for females, who at the time were disenfranchised, as for males, who would grow up to become voters." United Nations Educational, Scientific and Cultural Organization (UNESCO) proclamations of the later twentieth century, in which leaders of post-colonial nations pledge themselves to the goal of attaining universal basic education, feature statements of the key contributions that mass schooling has made to nationbuilding and the creation of citizens. One of the ironies of mass education is that the wider it spreads, the more likely its beneficiaries are to become aware of any curtailments to their own efficacy as citizens. Transmitting knowledge of citizenship along with norms of meritocracy, it appears inevitable that over time national systems of education will create the conditions within each nation for debate over those concerns that are included in multicultural education. As Torres observes in reference to Latin America, "the relationships between democracy, citizenship, and education cannot be treated in isolation from the question of multiculturalism." 12

It is only recently, however, that global public discourse on education has come to include the concerns of multiculturalism. As Torres further observes, multiculturalism is a theme that has been largely "ignored by the liberal state."13 Indeed, the "recognition of diversity" strand of multicultural education has proved problematic in many, if not most, national public dialogues on education. In the post-colonial "new nations," forming national unity took precedence over valorization of difference-notwithstanding intense struggles over the language, pedagogy, and religion that would define national identity. ${ }^{14}$ Authoritarian regimes, both capitalist and communist, silenced public debate over difference and inequality among citizens. Countries that acted as labor magnets, such as Germany and Japan, considered the education of both migrant and immigrant children as a separate matter from the education of citizens.

11. See Joel H. Spring, The American School: 1647-2000, at 110-11 (5th ed. 2001).

12. Carlos Alberto Torres, Education, Social Class and Dual Citizenship: The Travails of Multiculturalism in Latin America, in Global Constructions of Multicultural Education, supra note 1 , at 340 .

13. Id.

14. See generally Clifford Geertz, The Integrative Revolution: Primordial Sentiments and Civil Politics in the New States, in The Interpretation of Cultures: Selected Essays by Clifford GeERTz 255-310 (1973). 
With mass education so embedded in the nation-state and unifying concepts of citizenship, it is not surprising that one of the most historically common approaches to addressing pluralism in public schools is to mute it. Both republican and populist politics have privileged inclusion and equity in education over the recognition of difference in some nations. France stands out as an example of the former. The so-called "headscarf affair"15 of 1989, in which Muslim girls were sent home for refusing to remove their headscarves upon entry into public school buildings, resulted in the 2004 passage of a law banning all "ostentatious" displays of religious symbols. The law underscores how French notions of laïcité, or state secularism, differ from the line drawn between church and state in the United States. While U.S. political culture equates freedom of conscience with freedom of individual expression, in France the absence of the church from state institutions is reinforced by the near absence of religious symbolism from state-sponsored public spaces. Moreover, the very notion of French citizenship is that one gives up "particularisms, egotistic drives, and earlier traditions" in accepting the common rules of the French republican contract. ${ }^{16}$ Dussel draws an analogy between the French ban on headscarves and the wide-scale acceptance of the "white apron" in Argentina as a school uniform. ${ }^{17}$ The Argentine school system, like that of other post-colonial nations, was built to create a common identity among youth, with a special emphasis on assimilation of immigrants and equality of treatment between rich and poor. ${ }^{18}$ She points out that "[f]or many immigrants and children from low-income families, the possibility of an abstract equity and of hiding their backgrounds was appealing, for it implied a temporal release of the markers of difference." 19

Given the cultural logic of mass schooling in the nation-state, it is not surprising that educational debates framed by multiculturalism spread first to two nations whose political cultures share, to some extent, the emphasis on freedom of individual expression so evident in the United States. The term "multicultural education" entered public policy dialogues about education in Canada

15. See generally Elaine R. Thomas, Competing Visions of Citizenship and Integration in France's Headscarves Affair, 8 J. Eur. AREA STud. 167 (2000) (detailing the headscarf affair).

16. Inés Dussel, What Can Multiculturalism Tell Us About Difference? The Reception of Multicultural Discourses in France and Argentina, in Global Constructions of Multicultural EducaTION, supra note 1 , at 98.

17. See id. at $104-08$.

18. See id. at 104-06.

19. Id. at 106. 
and Australia in the early 1970s. In 1971, as Canada struggled over its language policy, the fourth volume of the Report of the Royal Commission was released by then-Prime Minister Pierre Trudeau. ${ }^{20}$ This volume dealt with linguistic and cultural matters of Canadians who were neither French nor English speaking. ${ }^{21}$ Trudeau presented the document to Parliament, recommending "a policy of multiculturalism within a bilingual framework." 22 In Australia, the term was first used by the Labor government's immigration minister in reference to new immigrants coming to Australia as a result of the 1973 amendments to immigration law that ended "the White Australia" policy. ${ }^{23}$

As early participants in dialogue on multicultural education, Canada and Australia continue to stand in contrast to the United States by virtue of having codified multicultural policies in education and other areas of public culture. ${ }^{24}$ Despite widespread public debate, policies related to multicultural education in the United States are either piecemeal, such as specific standards in state curriculum frameworks, or embedded in school district mission statements that lack compliance mechanisms. ${ }^{25}$

Several vectors of globalization have converged to raise the topic of multicultural education to the level of public, or at least professional, debate around the world today. The increasing cross-national mobility of people and the transnational communication of ideas that took place in the later twentieth century has fed into the contours of diversity around the world. It has also led to inter-

20. Pierre Elliot Trudeau, House of Commons Debates (1971), reprinted in Immigration and the Rise of Multiculturalism, at 136-37 (Howard Palmer ed., 1975).

21. Id.

22. Id.

23. J. Luketic et al., Pacific Waves, Television: Black and White or Color. Comparing Canadian and Australian Multicultural Broadcasting Initiatives (on file with author).

24. See Sabrina W. M. Laine \& Margaret Sutton, The Politics of Multiculturalism: A Three-Country Comparison, in The Politics of Multiculturalism and Bilingual Education: Students and Teachers Caught in the Cross-Fire 86 (Carlos J. Ovando \& Peter McLaren eds., 2000) ("The comparison of policies and approaches to multiculturalism in Australia, Canada, and the United States illustrates the wide range of public actions that can and have been taken by nations to address contemporary issues of ethnic and cultural pluralism.").

25. See generally Khaula Murtadha-Watts, Multicultural Curriculum and Academic Performance: African American Women Leaders Negotiating Urban School Accountability Policies, in Policy as Practice: Toward a Comparative Sociocultural Analysis of Educational Policy 103-22 (Margaret Sutton \& Bradley A. U. Levinson eds., 2001) (discussing the cross-cultural encounters between teachers and students in American public city schools and the tensions of diversity, multicultural education, and accountability standards). 
national dialogue on ways to address pluralism within national education systems. With increased human mobility and increasingly thick networks of communication, the common social fact of unequal educational experiences and outcomes is increasingly the subject of transnational dialogue. As Cornwell and Stoddard observe in the introduction to their volume entitled Global Multiculturalism: Comparative Perspectives on Ethnicity, Race and Nation, ${ }^{26}$ strategies for mobilizing political action around shared cultural identities are increasingly communicated and adapted across national boundaries. In this fashion, the term "multicultural education" has become recognizable to educators around the world. What is at stake and whether some form of multicultural education is desirable are highly contentious in most contexts.

\section{Linguistic Diversity and Cosmopolitan Languages}

Whether or not cultural differences per se have been addressed in specific national debates on public education, questions related to linguistic diversity have been hard to ignore in the creation and practices of national school systems. Language-in-education policies and practices are telling markers of the specific constructions of citizenship and national identity within each nation. They range from explicitly single language mediums, such as Germany and Japan, to official bilingualism in Canada and Belgium, to constitutional recognition of the right to education in the mother tongue, as in South Africa and India. In the area of language-in-education, two vectors of globalization are exerting conflicting forces in many societies today, complicating even further questions concerning cultural identity, group rights, and national citizenship. On the one hand, cultural revival movements around the world press for public use of vernacular languages. On the other, increasing cosmopolitanism creates a social demand for children to be educated in "world languages."

There is overwhelming technical evidence that the most efficacious approach to attaining literacy - a fundamental goal of mass education-is to introduce reading and writing in the mother tongue of the student, followed, if desirable, by a transition to literacy in a national language. Mother tongue in-

26. See generally Grant H. Cornwell \& Eve Walsh Stoddard, Introduction to Global Mult1culturalism: Comparative Perspectives on Ethnicity, Race and Nation (Grant H. Cornwell \& Eve Walsh Stoddard eds., 2001) (describing how one culture often exists outside of its defined national boundaries). 
struction is also explicitly endorsed within international human rights statements as a dimension of the human right to education. ${ }^{27}$ Providing formal schooling in the mother tongue, however, poses practical challenges in nations that are linguistically diverse in their formation, as well as those that have become linguistically diverse through migration. Written texts and trained teachers are scarce for many of the world's indigenous languages. In polyglot metropoles, the number of mother tongues represented in a single school or school system raises similar challenges, particularly to employing a linguistically representative teaching force.

Beyond these practical questions of the adequacy of linguistic resources for mother tongue education, political, economic, and cultural globalization is changing the political economy of languages. ${ }^{28}$ Demands for bilingual education by indigenous groups in Latin America provide an example. In Chile, as elsewhere in South and Central America, bilingual education comprising mother tongue and Spanish language education has been a common political demand of indigenous groups in the later twentieth century, often promoted by nongovernmental organizations (NGOs). ${ }^{29}$ The pressures of economic globalization, however, have led to a growing opposition to bilingual education efforts within some indigenous communities of Latin America. In Peru, for example, bilingual education, offered by local NGOs with government support, is rejected by many Quechua speaking parents. If schooling is to provide children access to economic resources in the future, it must teach them literacy in national and cosmopolitan languages. Thus, in some Andean communities, parents resist Quechua as a medium of instruction in schools. ${ }^{30}$

The Bologna Accords provide a policy framework that has generated similar tensions in nations of Eastern Europe that have recently joined the European

27. Economic, Social and Cultural Rights: Preliminary Report of the Special Rapporteur, U.N. ESCOR, Hum. Rts. Comm., 55th Sess., If 66, U.N. Doc. E/CN.4/1999/49 (1998).

28. See generally Pierre Bourdieu, Language and Symbolic Power (John B. Thompson ed., Gino Raymond \& Matthew Adamson trans., 1991) (noting that linguistic exchanges are relations of symbolic power in which the power relations between speakers or their respective groups are actualized).

29. See Guillermo Williamson \& Carmen Montecinos, Addressing Equity and Social Justice Concerns in Chile's Formal and Informal Education: An Historical and Contemporary Analysis, in GLOBAL Constructions of Multicultural Education, supra note 1, at 368.

30. María Elena García, The Challenges of Representation: NGOs, Education, and the State in Highland Peru, in Civil Society or Shadow State?: State/NGO Relations in Education (Margaret Sutton \& Robert F. Arnove eds., 2004). 
Union. The Accords dictate that minority language maintenance and development must be supported by European Union (EU) member nations. This mandate has provided a platform for language revival activists, including speakers of the Võro language in southern Estonia. There, the Vorro Language Institute has been successful in creating curricular materials to provide Võro language instruction for a few hours a week in local schools. As in the Peruvian Andes, however, the community of Vōro speakers has mixed judgments of the benefits of incorporating mother tongue instruction into formal education. It would make sense to many parents that formal language instruction in the schools include English, French, or other metropolitan languages rather than mother tongue enhancement. ${ }^{31}$

As English has gained dominance as the cosmopolitan language, pressure has increased to offer English medium instruction, or at least English as a foreign or second language even in the most remote communities of Africa and South Asia. Community aspirations for child ren to become linguistically cosmopolitan have been realized in many nations through the vehicle of private schooling, an increasingly common phenomenon in post-colonial nations. As noted by Tomasevski, privatization of education is one of the major dimensions of globalization in contemporary educational systems. ${ }^{32}$ Whether as a result of policy conditions placed on governments by international financial institutions or as a governmental response to citizens' demands for greater choice in education, the legal framework for provision of schooling has changed in many nations, opening spaces for non-state providers. Little systematic research has been conducted on the growing private sector of basic education, particularly in Asia and Africa. However, one need only visit rural areas in Nepal, Indonesia, Tanzania, and elsewhere to observe that English medium instruction is a powerful incentive for parents to pay school fees.

Globalization thus exerts contradictory forces on linguistic diversity in the schools and language-in-education policies. On the one hand, universal human rights norms support the development of bilingual education policies and practices for children who speak minority languages. These norms are communicated and codified by regional and international treaties. Global communication

31. Kara D. Brown, "Like Lace on the Bottom of a Curtain": Regional Language Policy, the European Union, the Estonian Government, and the Vorro Institute in Estonia, in CIVIL SOCIETY OR SHADOw State? State/NGO Relations in Education, supra note 30, at 109.

32. See generally Katarina Tomasevski, Globalizing What: Education as a Human Right or as a Traded Service?, Ind. J. Global Legal Stud., Winter 2005, at 1. 
enables language minority communities to exchange and adapt strategies for activism. Both activism and these norms thus exert a pressure for linguistic diversity. At the same time, economic globalization has heightened demands around the world for formal education in national and cosmopolitan languages, thus exerting pressure for greater linguistic homogeneity, specifically reinforcing the dominance of English as a global language.

\section{Intercultural Education: A Model for Global Multiculturalism}

Global migration and communication, the spread of neoliberal policies supporting private schooling, and the opening of spaces for public discourse in formerly authoritarian regimes have all contributed to raising the salience of multicultural issues in public discourse on education. They have also complicated thinking around the world on what cultural identity means, what it has to do with national and cosmopolitan identities, and what all of this has to do with the institution of schooling. Educators around the world are faced with new challenges of balancing local, national, and global norms and values in the process of educating children. While fostering a sense of citizenship remains an important function of mass schooling, it is becoming less and less viable to do so at the expense of socializing children for their futures in a global society. While each community and nation will continue to work out these challenges within the topography of diversity unique to that nation, one general orientation toward multiculturalism that seems most adaptable to the global culture of today is the European-based movement called "intercultural education." 33 Because the most visible minority groups in Western Europe are what John Ogbu refers to as "voluntary minorities," 34 or immigrants motivated by economic goals, demands for minority recognition in Europe have met less general endorsement by the citizenry than have similar demands made by "involuntary minorities" in the Americas, notably indigenous people and the descendents of slaves. ${ }^{35}$ Nonetheless, educators in western Europe, as elsewhere, are in the front lines of cultural transformation, faced with the task of raising new generations that are culturally pluralistic. The Council for Cultural

33. See generally Dussel, supra note 16, at 93-111.

34. See generally John U. Ogbu, Variability in Minority School Performance: A Problem in Search of an Explanation, 18 ANthropology \& Educ. Q. 312 (1987).

35. See generally id. 
European Cooperation endorses the perspective conveyed by the term "intercultural" as a framework for educating in the now universal context of cultural pluralism. "Intercultural education" or "education toward the whole of the community" ${ }^{36}$ has the virtue of softening the edges of identity politics while conferring legitimacy on diverse cultural identities. It also shifts pedagogical focus to educating the majority as well as minority communities, rather than, as in the United States, allowing multicultural education to be associated primarily with the education of minority groups. The pedagogical challenge of interculturalism will remain the maintenance of the social justice edge of multicultural education in the face of simple celebration of diversity.

36. Miguel A. Santos-Rego \& Servando Pérez-Dominguez, Intercultural Education in the European Union: The Spanish Case, in Global Constructions of Multicultural Education, supra note 1 , at 240 n.2. 